\title{
THE
}

\section{Assessing the Efficiency of Local Open Space Provision}

Corey Lang

University of Rhode Island, clang@uri.edu

Follow this and additional works at: https://digitalcommons.uri.edu/enre_facpubs

The University of Rhode Island Faculty have made this article openly available.

Please let us know how Open Access to this research benefits you.

This is a pre-publication author manuscript of the final, published article.

Terms of Use

This article is made available under the terms and conditions applicable towards Open Access

Policy Articles, as set forth in our Terms of Use.

Citation/Publisher Attribution

Lang, C. (2018). Assessing the Efficiency of Local Open Space Provision. Journal of Public Economics, 158, 12-24. doi:10.1016/j.jpubeco.2017.12.007

This Article is brought to you for free and open access by the Environmental and Natural Resource Economics at DigitalCommons@URI. It has been accepted for inclusion in Environmental and Natural Resource Economics Faculty Publications by an authorized administrator of DigitalCommons@URI. For more information, please contact digitalcommons-group@uri.edu. 
Forthcoming, Journal of Public Economics

\title{
Assessing the EfFiciency of LOCAL Open Space Provision
}

\author{
Corey Lang* \\ Department of Environmental and Natural Resource Economics \\ University of Rhode Island
}

\begin{abstract}
This paper tests the efficiency of local provision of land conservation. I examine how housing prices, which capitalize open space amenities and future tax obligations, change after municipalities vote on referendums for conservation spending. Using a dynamic regression discontinuity based on voting outcomes, results suggest that average housing prices increase about 0.68-1.12\% for every $\$ 1000$ per household of open space spending authorized, which indicates inefficiency and underprovision of conservation. I also examine tax capitalization and supply side explanations for estimated capitalization.
\end{abstract}

Keywords: local public finance; open space; hedonic valuation; regression discontinuity; voting; referendum; tax capitalization; homevoter hypothesis JEL codes: D72, H41, H76, Q24, Q51

\footnotetext{
*214 Coastal Institute, 1 Greenhouse Rd., Kingston, RI, 02881. Email: clang@uri.edu. I thank Nick Kuminoff, Kathy Baylis, Matt Freedman, Laura Grant, Sumeet Gulati, Martin Heintzelman, Sarah Jacobson, Lucija Muehlenbachs, Pat Prendergast, Kathy Segerson, seminar participants at Binghamton University, University of Connecticut, University of Illinois, University of Massachusetts, Camp Resources, ASSA, NAREA, the Heartland Workshop, and AERE, and two anonymous referees for valuable comments. Matt Altonji and Carrie Gill are thanked for excellent research assistance. This work was supported by the USDA National Institute of Food and Agriculture, Agricultural and Food Research Initiative Competitive Program, Agriculture Economics and Rural Communities, grant number: 2015-67024-22937.
} 


\section{INTRODUCTION}

A fundamental uncertainty in economics is the efficiency of local provision of public goods. Tiebout (1956) showed that a market solution exists to the local public good problem, namely that households shop for a residential location that offers the optimal bundle of services, taxes, and housing prices given their budget. Through competition for residents, local governments respond to demand, and an efficient allocation of public goods is attained. Despite this theoretical optimism, there are reasons that inefficient provision may be prevalent. First, the necessary equilibrium conditions of Tiebout are extreme and often rejected by empirical findings (Ross and Yinger 1999). Second, academic and especially political concerns persist about Leviathan governments maximizing budgets beyond the point of efficiency. Third, at least partially in response to those concerns, all but a few states either severely limit tax increases or require municipalities to hold votes to raise taxes or issue bonds (Ballotpedia 2016), which may lead to inefficient under-provision of services by limiting the ability of local governments to respond to demand. ${ }^{1}$

This paper examines the efficiency of local public good provision in the context of open space conservation. Urban sprawl has been a major trend in the United States over the last 60 years. The number of people living in suburban areas increased 154\% between 1960 and 2000, triple the rate of overall population growth (Hobbs and Stoops 2002). With this expansion comes the development of open space lands in the urban-rural fringe; U.S. Forest Service (2016) estimates that 5760 acres of open space are developed every day in the United States. Open space provides myriad benefits for people, spanning recreation and visual amenities to ecosystem services and rural character. ${ }^{2}$ However, the sum of these benefits for a community's residents is not internalized by private landowners, and thus land conservation is an important public good provided by local governments, as well as state and federal governments and NGOs.

The specific empirical setting I consider is municipal open space referendums, which if passed will raise taxes to pay for permanent conservation of undeveloped lands through outright

\footnotetext{
${ }^{1}$ Forty-one states require a municipal vote to raise taxes or issue bonds (Ballotpedia 2016), and this had led to a prevalence of local referendums. For example, California municipalities alone hold about 500 referendums per election (Ballotpedia 2016) and municipal referendums have been held in 57 of 58 counties between 1998-2012 (Legislative Analyst's Office 2014); 98.4\% of Ohio’s municipalities voted on property tax increases for education during 1990-2007 (Isen 2014); 85\% of Rhode Island's municipalities voted on some type of local referendum in either 2012 or 2014 (Rhode Island Board of Elections 2016).

2 The term open space encapsulates many land uses, including forests, wetlands, prairie, hiking trails, agriculture, parks, sports fields, and more. The unifying feature is a lack of built environment.
} 
purchase or more often purchase of development rights. The test of efficiency, which stems from the seminal work of Oates (1969) and Brueckner (1979), examines how municipal housing prices respond if a referendum is passed and hence taxes are raised. Housing prices reflect the net of households' valuation of locally conserved land and the cost of taxes. If prices are unresponsive, then public goods are efficiently provided. However, if prices change, this indicates inefficiency, with increasing prices pointing to underprovision and decreasing prices overprovision. To address this question, I build a panel dataset of 1,145 municipal referendums occurring in the United States and community-level median housing prices from Zillow for years 1997-2013.

An empirical concern when estimating the relationship between housing prices and municipal land conservation spending is the endogeneity of spending levels. To mitigate this endogeneity, I take advantage of the fact that sample municipalities vote to authorize conservation spending and implement a regression discontinuity (RD) research design based on voting outcomes. Essentially, I compare house price changes in communities that barely pass a referendum to those that barely fail. This framework stems from a substantial literature that has used election outcomes for causal inference (e.g., Lee et al. 2004, Lee 2008, Solé-Ollé and Viladecans-Marsal 2013, Albouy 2013, Martorell et al 2016, Jerch et al. 2017). ${ }^{3}$

The standard RD design is complicated by two aspects of municipal open space referendums. First, municipalities can and do hold more than one referendum, which necessitates incorporating dynamics into the model. Following the model developed by Cellini et al. (2010), I implement a dynamic RD estimator that conditions treatment effects on other referendums a community has held. Second, these referendums often couple open space funding with funding for other uses, such as affordable housing and historic preservation. If the house price impacts of open space spending are different than spending on other priorities, then the estimated effect of simply passing a referendum will be an average of those impacts and a biased estimate of open space valuation. To address this, I modify the dynamic RD design to include approved funding amounts for each type of spending, normalized by the number of housing units in a municipality, instead of a binary pass variable.

The results suggest that $\$ 1,000$ per household of referendum authorized open space spending increases housing prices in the range of $0.68-1.12 \%$ in years one through 10 post

\footnotetext{
${ }^{3}$ Caughey and Sekhon (2011) raise concerns about necessary assumptions being false in electoral RD designs, but Eggers et al. (2015) largely validate the practice.
} 
approval, with an upward trend over time. In contrast, spending on other purposes (e.g., affordable housing, historic preservation) has a statistically insignificant impact on housing prices. This suite of results is robust to a number of functional form assumptions and changes in the selection of the sample. While land conservation provides amenities, it also reduces the supply of developable land. As a result, the estimated price response may be a combination of these forces, which push prices in the same direction and are difficult to disentangle. ${ }^{4}$ However, additional tests involving geographic restrictions in supply (in the vein of Saiz 2010) and construction responses do not support a supply side effect.

There are three primary contributions of this paper. First, this paper adds new findings to the debate over the efficiency of local public good provision. While Tiebout's (1956) model suggests efficient provision, other theoretical work argues overprovision is likely (Yinger 1985, Caplan 2001). Empirical work has had mixed findings as well with Brueckner (1979) indicating overprovision, Brueckner (1982) efficient provision, and Barrow and Rouse (2004) and Cellini et al. (2010) underprovision. My findings of positive capitalization suggest that increasing open space increases efficiency, as households value the conserved land more than the costs of conservation. The vast majority of papers empirically testing efficiency do so in the context of aggregate municipal expenditures or school expenditures. ${ }^{5}$ Interestingly, the ratio of capitalization to taxes is larger in my paper than in Barrow and Rouse (2004) and Cellini et al. (2010), which both examine school expenditures. One interpretation of this comparison is that while education and open space are both underprovided, open space provision is relatively more inefficient, which could result from households optimizing location choice over multiple public goods and school quality being more of a priority than open space.

Second, this paper offers two empirical tests of important assumptions in local public finance. The first is that municipal taxes are capitalized into housing prices: if two identical houses are located in municipalities with different tax rates, then the values of the two houses will differ by exactly the difference in present value of the stream of future tax payments. While

\footnotetext{
${ }^{4}$ Balsdon (2012) elucidates these dual motivations for land conservation voting particularly well. He finds some but not conclusive evidence that voting decisions are affected by homeowner rent seeking.

${ }^{5}$ One example outside these contexts and closely related to this paper is Heintzelman (2010), who examines the efficiency of municipal open space spending in Massachusetts. Besides scope of sample, the key differences are his use of a difference-in-differences research design and estimating the effect of passing a referendum without decoupling spending for open space and spending for other purposes. He finds on average a negative house price response indicating overprovision, but some heterogeneity exists across different counties.
} 
perfectly intuitive, this is difficult to empirically validate given that taxes and local public goods are highly correlated. Do and Sirmans (1994) and Palmon and Smith (1998) use settings in which the tax rates differ between two areas but the services do not and find strong evidence of full capitalization and reasonable discount rates. In contrast to these papers and others testing tax capitalization that use cross sectional variation, my test of tax capitalization uses within variation and posits that capitalization should increase over time as future tax obligations decrease but public goods stay constant. The results do suggest capitalization increases over time by a magnitude that is reasonably consistent with expectations, thus supporting the theory of tax capitalization. The second theory is Ficshel's (2001) homevoter hypothesis. In his book, he argues that homeowners will vote on local public finance issues with the value of their house in mind. In model specifications that just focus on pass versus fail and do not disaggregate funding, the results suggest no statistically significant house price capitalization. This finding is consistent with the homevoter hypothesis because in the RD design median voters in referendums near the threshold are indifferent. This result adds to the seminal work of Sonstelie and Portney (1980), as well as the more recent Dehring et al. (2008) and Aldfeldt and Maennig (2015), who also find empirical support for the homevoter motivation.

Third, this paper contributes to the literature on the valuation of open space by applying concepts from local public finance. Hedonic valuation of open space is a familiar topic in environmental and urban economics; McConnell and Walls (2005) survey the literature and identify 40 hedonic studies focused on open space through 2003, and there have been dozens more since then. ${ }^{6}$ Typically, these papers use proximity to open space as the key identifying variation to estimate willingness to pay (e.g., Irwin 2002, Anderson and West 2006). A concern here is that only the differential benefit of conservation can be estimated, and total benefits may be larger as they extend to non-proximate households (Abbott and Klaiber 2011). In contrast, I focus on municipal decisions of open space provision and assess the efficiency of the level of provision.

\footnotetext{
${ }^{6}$ In addition, there is a substantial literature seeking to estimate demand for open space using voting data (e.g., Deacon and Shapiro 1975, Altonji et al. 2016, Burkhardt and Chan 2017), including several using the same LandVote data used in this paper (e.g., Kotchen and Powers 2006, Nelson et al. 2007, Banzhaf et al. 2010, Heintzelman et al. 2013, Kroetz et al. 2014).
} 


\section{THEORETICAL FRAMEWORK}

This section describes a simple theoretical framework that illustrates the logic of the paper. The gist of the model is as follows. First, all households choose where to live based on amenities, housing prices, taxes, and their budget. Having chosen a location, households can vote to increase taxes in order to increase local public goods provision. If public goods do change, then housing values will likely change due to some households re-optimizing their location decision. Through the theory, three testable predictions are derived: a test of the efficiency of local public good provision, a dynamic test of tax capitalization, and a test of the homevoter hypothesis. I now present the formal model, which draws on the models of Brueckner (1979) and Cellini et al. (2010), as well as the arguments of Fischel (2001).

There are $J$ communities that are distinguished by different levels of public goods, such as schools and open space, and different housing costs and tax rates. Think of these $J$ communities as being in the same metro area, and moving is costless among the $J$ communities, but is prohibitively expensive to move to another metro area. Households prefer higher levels of public goods all else equal, but they are costly to enjoy as tax burdens and housing costs will be greater in high public good communities. In choosing where to live, household $h$ seeks to maximize utility over the set of $J$ locations subject to a budget constraint:

$$
\begin{gathered}
\operatorname{Max}_{\{j\}} U_{h}\left(A_{j}\left(r_{j}\right), X_{j}, c_{h}\right) \\
\text { subject to } w_{h} \geq c_{h}+p_{j}+r_{j}
\end{gathered}
$$

Where $A_{j}$ is a measure of the quality of local, government supplied public goods in community $j$, which is a function of $r_{j}$, the community-specific annual taxes (i.e., property taxes) paid to support public goods. $A_{j}^{\prime}\left(r_{j}\right)>0$, but could be small if government is inefficient. $X_{j}$ is a vector of location attributes that are not supplied through taxation, such as commuting distance to work, $c_{h}$ is consumption of a numeraire good, $w_{h}$ is income, and $p_{j}$ is the annual price of housing. For now, consider taxes and housing prices fixed in all communities.

Households choose to live in a community with the locus of prices and public goods that best fits their preferences. From Equation (1), we can define the indirect utility of household $h$ as $U_{h}\left(A_{j}\left(r_{j}\right), X_{j}, w_{h}-p_{j}-r_{j}\right)$. Then the Implicit Function Theorem defines the household's 
maximum bid for housing in community $j, g_{h j}=g_{h}\left(r_{j}, X_{j}\right) .{ }^{7}$ Household $h$ will choose community $j$ if $p_{j} \leq g_{h j}$.

Equilibrium in the housing market is defined as a set of taxes and prices $\left(r_{j}{ }^{*}, p_{j}{ }^{*}\right)$ for all $J$ and housing allocations such that no household could be made better off by moving. In order for equilibrium to be reached, housing prices will adjust until supply equals demand in each community. If the number of households that choose community $j$ based on prices $p_{j}$ exceeds the number of housing units in community $j$, then prices will increase above the maximum bid of some households and those households will choose a different community.

For several reasons, such as heterogeneity in preferences over $A_{j}$ and $X_{j}$, it is possible that a household would prefer a level of $r_{j}>r_{j}{ }^{*}$, even when $j$ is their preferred community in equilibrium. ${ }^{8}$ The $N_{j}$ residents of community $j$ can vote to authorize increasing $r_{j}$ to better fit their preferences. Suppose there is a referendum in community $j$ to raise taxes to $r_{j}{ }^{* \prime}>r_{j}{ }^{*}$. If the referendum passes, households will re-sort among the $J$ communities to maximize utility, which may impact housing prices. By differentiating the implicit function that defines $g_{h}\left(r_{j}, X_{j}\right)$, we can investigate how housing bids would respond to a change in taxes:

$$
\frac{\partial g_{h}\left(r_{j}, X_{j}\right)}{\partial r_{j}}=\frac{\frac{\partial U_{h}}{\partial A_{j}} \cdot \frac{\partial A_{j}}{\partial r_{j}}}{\frac{\partial U_{h}}{\partial c_{h}}}-1=\frac{\frac{\partial U_{h}}{\partial A_{j}} \cdot \frac{\partial A_{j}}{\partial r_{j}}-\frac{\partial U_{h}}{\partial c_{h}}}{\frac{\partial U_{h}}{\partial c_{h}}}
$$

Equation (2) shows that housing bids increase if the product of the utility value of public goods $\left(\partial U_{h} / \partial A_{j}\right)$ and the efficiency of government to provide those goods $\left(\partial A_{j} / \partial r_{j}\right)$ exceeds the utility lost from forgone consumption $\left(\partial U_{h} / \partial c\right)$ due to paying extra taxes. We can think of Equation (2) describing an inverse-U relationship between housing prices and public good levels. The efficient level of public goods is when $\partial g_{h} / \partial r_{j}=0$, that is housing prices are unresponsive to marginal changes in taxes. At inefficiently low levels of public goods, increases in taxes will cause housing prices to increase, $\partial g_{h} / \partial r_{j}>0$. And lastly, at inefficiently high levels of public goods, increases in taxes will cause housing prices to decrease, $\partial g_{h} / \partial r_{j}<0 .{ }^{9}$

\footnotetext{
${ }^{7} g_{h}(\cdot)$ is defined implicitly by $U_{h}\left(A_{j}\left(r_{j}\right), X_{j}, w_{h}-g_{h}\left(r_{j}\right)-r_{j}\right)=\max _{\mathrm{k} \neq j} U_{h}\left(A_{k}\left(r_{k}\right), X_{k}, w_{h}-p_{k}-r_{k}\right)$.

${ }^{8}$ In addition to the aforementioned tax constraints placed on municipalities by states, Bayer and McMillan (2012) empirically demonstrate that the presence of multiple location attributes can disrupt a Tiebout equilibrium.

${ }^{9}$ Coate (2013) argues that analyses examining house price responses to government spending, such as this paper and Cellini et al. (2010), are not theoretically grounded because homeowners with rational expectations should expect a
} 
The increase in public goods resulting from the increase in taxes generates value through amenities that accrue to residents. Marginal willingness to pay (MWTP) is the present value of the infinite stream of amenity values discounted at rate $i$ :

$$
M W T P_{j}=\sum_{t=1}^{\infty}(\text { annual amenity value })(1+i)^{-(t-1)}
$$

While current owners benefit from amenity values, they must pay increased taxes in order to continue to live there. Because owners are indifferent between staying and moving (potential buyers are indifferent as well), the change in house value (capitalization) will be the difference between MWTP and the present value of the future tax burden, $F T B_{t}(\cdot):^{10}$

$$
\text { Capitalization }_{j t}=M W T P_{j}-F T B_{t}\left(r_{j t}{ }^{* \prime}-r_{j t}{ }^{*}\right)
$$

This equation introduces a time subscript, which was omitted above for simplification. The reason for this is that while improving some public goods requires a permanent increase in taxes, other cases (e.g., land conservation, school infrastructure) require a finite investment. This is consistent with bond financing, which allows a community to pay a large upfront cost and entails a term repayment. In the context of voting on referendums, the year of the referendum is $t=0$, the year after the referendum is $t=1$, and so on. If the referendum passes, taxes are first increased at $t=1$. If tax increases are term, then $F T B_{t}(\cdot)$ will decrease over time and eventually equal zero, hence the need for time subscripts. While the temporal evolution of tax payments in unknown to the researcher, the total tax bill is known and equals $F T B_{1}$. Thus, capitalization at $t=1$ is the estimable version of Equation (2) that defines the test of efficiency:

Test of Efficiency:

$$
\text { If Capitalization }{ }_{j 1}\left\{\begin{array}{l}
>0 \\
=0 \\
<0
\end{array}\right\} \text { then } A_{j}\left(r_{j}^{*}\right) \text { is }\left\{\begin{array}{c}
\text { inefficiently underprovided } \\
\text { efficiently provided } \\
\text { inefficiently overprovided }
\end{array}\right\}
$$

This test assumes that market capitalization of amenity improvements and taxes is immediate.

certain level of public services and not be surprised by passage of new spending. However, there are two reasons to believe this may not hold. First, as noted in the introduction, many states require voter authorization to increase taxes. Second, an open space referendum may be fundamentally different than school funding due to the irreversibility of land development. While a failed education referendum may have little long term effect as later funding can be adjusted, a failed open space referendum may lead to development of an important parcel of land. ${ }^{10}$ Kuminoff and Pope (2014) caution against equating capitalization and MWTP. 
While assessing efficiency is the primary goal, this theory has testable implications for how taxes are capitalized into home values. ${ }^{11}$ Equation (4) implies that for two time periods $t$ and s, Capitalization $_{j t}-F T B_{j t}=$ Capitalization $_{j s}-F T B_{j s}$. Because benefits of public goods stay constant, tax bill declines will be perfectly absorbed into housing prices to maintain equilibrium. In the context of finite increases in taxes, this implies that capitalization will increase over time.

Test of Tax Capitalization: If $t>s>0$ and $F T B_{t}(\cdot)<F T B_{s}(\cdot)$, then

$$
\text { Capitalization }_{j t}>\text { Capitalization }_{j s}
$$

Lastly, this model can speak to voting behavior. In his book The Homevoter Hypothesis, Fischel argues that homeowners will vote on local public goods based on how the proposed spending change will impact their property values. In the context of this model, the initial vote on a referendum will be influenced by the expected capitalization the spending would cause.

Test of the Homevoter Hypothesis:

$$
\text { If Capitalization } \text { }_{j 1}\left\{\begin{array}{l}
>0 \\
=0 \\
<0
\end{array}\right\} \text { then homeowners of } j \text { will }\left\{\begin{array}{c}
\text { vote in favor } \\
\text { be indifferent } \\
\text { vote against }
\end{array}\right\}
$$

However, this prediction rests on the assumptions that residents vote based only on capitalization and their expectations about capitalization are correct.

The tests of efficiency, tax capitalization, and the homevoter hypothesis all depend on the estimated capitalization, which is the major focus of the next several sections of the paper. Once the price response is estimated, I will return to these tests.

\section{OPEN SPACE REFERENDUMS: BACKGROUND AND DATA}

Public referendums have become an important and popular tool to raise funds for open space conservation. According to The Trust for Public Land (2013), over $\$ 72$ billion have been raised for conservation through referendums since 1988, which is about $\$ 2.6$ billion per year. In comparison, the federal government spends about $\$ 2.5$ billion for the conservation reserve

\footnotetext{
${ }^{11}$ Equation (2) assumes perfect tax capitalization, but does not generate a testable hypothesis because tax and amenity capitalization cannot be separated.
} 
program (Nelson et al. 2007), and the 2014 annual programmatic expenses of The Nature Conservancy was $\$ 541$ million. ${ }^{12}$

While states and counties hold open space referendums, the focus of this paper is on municipalities that raise funds in this manner. The reason for this focus is to test the efficiency of municipal open space provision, consistent with prior tests of local public good efficiency (Oates 1969, Brueckner 1979, 1982). Further, the benefits of preservation are concentrated, in contrast to county and especially state efforts. Municipalities holding referendums are typically in the rural-urban fringe where development pressure is highest. Figure 1 illustrates the spatial distribution of referendum municipalities, using the Minneapolis-St. Paul metro area. The figure shows that communities holding referendums are in suburban areas within commuting distance to the center city.

Referendum data come from the Trust for Public Land's (2013) Land Vote Database. For each proposed municipal referendum, the data include the date held, percentage of yes votes received and required to pass, proposed amount of funding, and vehicle to raise funds (i.e., bonds or property taxes). Importantly, the amount of proposed funding is split between funds intended for open space conservation and funds for other purposes, typically historic preservation and construction of public housing. Sample construction is discussed along with the Zillow housing data in Section 5.

Table 1 gives summary statistics of municipal open space referendums included in the analysis by year. There were few referendums in the 1980s through the mid-1990s, then activity increased substantially in the late 1990s and continued through the mid-2000s, until pace slowed again. The average municipal referendum proposes $\$ 9.1$ million in total funding, of which $\$ 6.7$ million is dedicated to conservation. I normalize proposed and authorized spending by the number of housing units in a municipality. This allows for comparison across more and less populous municipalities and gives the approximate present value of future tax burden, $F T B_{1}$. The average amount of spending proposed is $\$ 1,132$ per housing unit. On average, $75 \%$ of that funding is dedicated to open space, with $25 \%$ going towards other functions. While not shown in the table, $98.1 \%$ of referendums require a $50 \%$ approval share for passage; the remainder requires either $60 \%$ or two-thirds majority.

\footnotetext{
12 http://www.nature.org/about-us/our-accountability/annual-report/2014-financial-report-with-report-ofindependent-auditors.pdf
} 
Open space referendums are very popular, as demonstrated by columns 5-7 of Table 1. Referendums pass on average $76 \%$ of the time, and often pass with a margin exceeding $10 \%$. Further, it is common for municipalities to hold more than one referendum over this time span. Of the entire sample of referendums, about 38\% occur in a municipality that has held an open space referendums previously. Since 2002, the proportion is about 53\%, and since 2006, the proportion is $67 \%$. Incorporating this dynamic behavior to hold multiple referendums is critical for estimating capitalization and motivates the dynamic aspect of my research design. Failure to include dynamics will result in estimating an intent to treat effect, which may be downward biased if municipalities that fail to pass try again and succeed (Cellini et al. 2010, Isen 2014).

\section{EMPIRICAL RESEARCH DESIGN}

This section describes the dynamic regression discontinuity design in steps, starting with simple models and adding complexity. Suppose municipality $j$ considers a ballot initiative and votes in favor of the referendum with vote margin $v m_{j}$, which equals the percent of yes votes minus the required percent for a pass. Let $\operatorname{pass}_{j}=1\left(v m_{j} \geq 0\right)$ be an indicator for passing the referendum. Ignoring time considerations for the moment, the effect of passing an open space referendum on outcome $y_{j}$ (i.e., housing price) can be modeled as:

$$
y_{j}=\beta+\vartheta \operatorname{pass}_{j}+\varepsilon_{j}
$$

where $\vartheta$ is the coefficient of interest. However, $\vartheta$ is likely to be biased due to unobserved characteristics that determine the outcome and are correlated with passing a referendum. To mitigate this problem, an RD design could be applied that essentially compares municipalities that just barely pass a referendum to those that just barely fail. In a narrow spectrum of $v m_{j}$ around the threshold, unobservables should be uncorrelated with $v m_{j}$ and, critically, whether a referendum passes or fails is as good as random. Equation (7) additionally controls for $v m_{j}$ using a flexible polynomial with corresponding parameters $\gamma$ :

$$
y_{j}=\beta+\vartheta \text { pass }_{j}+f\left(v m_{j}, \gamma\right)+\varepsilon_{j}
$$

Now, $\vartheta$ is unbiased and estimates the causal effect of referendum passage on an outcome, under the assumption that other determinants of $y_{j}$ are continuous around $v m_{j}=0$.

The current setting involves municipalities holding and passing multiple referendums and observing multiple years of outcome data, and thus the static framework of Equations (6) and (7) 
needs to be extended to account for these complexities. The outcome variable is now indexed by calendar year $t, y_{j t}$, and pass $_{j t}$ equals one if municipality $j$ passes a referendum in year $t$ and zero otherwise. Because passing a referendum can affect the outcome in subsequent years beyond the year of the referendum, I model the outcome as a function of all prior referendum history (abstracting from the RD component):

$$
y_{j t}=\sum_{\tau=0}^{\bar{\tau}} \vartheta_{\tau} \text { pass }_{j, t-\tau}+\delta_{j}+\pi_{t}+\varepsilon_{j t}
$$

where $\tau$ is the number of years since the referendum $\delta_{j}$ is a municipality fixed effect, and $\pi_{t}$ is a year by census division fixed effect. Because the scope of this study is national and housing prices have many local and regional determinants, I need to control for house market trends that may be correlated with referendum passage. The year by census division fixed effects are a first step. Additionally, using Zillow data (detailed in the next section), I construct an annual price index for each county, equal to the logged average Zillow price index for each zip code within a county. Then, I include this index as an independent variable in all house price specifications to capture more local variation in market trends. Ideally, state-by-year or even MSA-by-year fixed effects could be included, but these overwhelm the data. In Equation (8), $\vartheta_{\tau}$ measures the effect of passing a referendum $\tau$ years ago, conditional on other referendum passes. Thus, this equation measures treatment on the treated.

Combining the RD elements of Equation (7) with the dynamic elements of Equation (8), the dynamic RD model developed by Cellini et al. (2010) is formed:

$$
y_{j t}=\sum_{\tau=0}^{\bar{\tau}}\left[\vartheta_{\tau} \text { pass }_{j, t-\tau}+\alpha_{\tau} b_{j, t-\tau}+f\left(v m_{j, t-\tau}, \gamma_{\tau}\right)\right]+\pi_{t}+\delta_{j}+\varepsilon_{j t}
$$

where $b_{j, t-\tau}$ acts as an intercept and is a binary variable equal to one if municipality $j$ holds a referendum at time $t-\tau$ and the polynomial in vote margin is allowed to vary across lagged years.

Cellini et al. additionally estimate a dynamic RD model that substitutes the amount of money authorized in the referendum, $f u n d s_{j, t-\tau}$, for $p a s s_{j, t-\tau}$ as the key independent variable:

$$
y_{j t}=\sum_{\tau=0}^{\bar{\tau}}\left[\vartheta_{\tau} \text { fund } s_{j, t-\tau}+\alpha_{\tau} b_{j, t-\tau}+f\left(v m_{j, t-\tau}, \gamma_{\tau}\right)\right]+\delta_{j}+\pi_{t}+\varepsilon_{j t}
$$


I modify this last equation in two ways to arrive at my preferred specification. First, due to the fact that referendum-authorized spending is split between open space and other purposes, such as public housing and historic preservation, I adjust the specification to separate those types of funding:

$$
\begin{aligned}
y_{j t}=\sum_{\tau=0}^{\bar{\tau}} & {\left[\vartheta_{\tau} \text { open }_{j, t-\tau}+\rho_{\tau} \text { other }_{j, t-\tau}+\alpha_{\tau} b_{j, t-\tau}+f\left(v m_{j, t-\tau}, \gamma_{\tau}\right)\right] } \\
& +\delta_{j}+\pi_{t}+\varepsilon_{j t}
\end{aligned}
$$

where $o p e n_{j, t-\tau}$ and $o t h e r_{j, t-\tau}$ are the amounts of funding devoted for open space and other purposes, respectively. Equation (11) has the causal interpretation and dynamic components of Equations (9) and (10), but allows for open space spending and spending for other purposes to have different impacts on the outcome. For example, if households view open space as an amenity but public housing as a disamenity, $\vartheta_{\tau}$ and $\rho_{\tau}$ may have opposite signs.

The second modification is to add proposed funding amounts for open space and other as additional control variables. This stems from a concern that the amount of funding proposed may be endogenous. By controlling flexibly for vote margin, whether or not a referendum passes is quasi-random close to the threshold. But that is not true for the proposed budget; there may be unobserved determinants of house prices that are correlated with amount of funding. By controlling for proposed funding, this endogeneity will be captured.

Equation (11) with the addition of proposed funding is the preferred specification. $\vartheta_{\tau}$ is interpreted as the causal effect of referendum approved spending on open space $\tau$ years after passage, conditional on other referendums municipality $j$ has held. This is a local average treatment effect and only holds for sample municipalities near the threshold.

\section{DATA AND SAMPLE CONSTRUCTION}

House price data come from Zillow's home value index (ZHVI) at the zip code level, the finest spatial scale available. Zillow data are being increasingly used in hedonic analyses (e.g., Huang and Tang 2012, Weber et al. 2016) because they are publicly available, national in scope, and unbiased estimates of actual sales (Bruce 2014). Zillow estimates the value of each house within a zip code based on recent, nearby sales and hedonic adjustments for property specific characteristics. Thus, Zillow captures the whole distribution of the housing stock and not just the distribution of sales in any one time period. This is important in the event that the types of 
houses being sold change after a referendum passes. It also obviates the need to control for housing characteristics, as in a typical hedonic regression. Zillow takes the median estimated price for each zip code, applies a 5-month moving average and seasonal adjustment, and then reports this as ZHVI. ${ }^{13}$ The data were downloaded in November 2013 at the month-zip code level and date back to January 1997. In order to build a zip-year panel, I averaged observations for months May through October, which correspond to peak season of transactions and the months prior to November when most referendums occur. Averaging across months and omitting November through April has the additional benefit of removing serial correlation created by the moving average involved in the construction of ZHVI.

There are a total 1,747 municipal referendums held in the continental United States during 1988-2012. Municipalities were manually matched to zip codes using multiple sources such as town websites, zipmap.net and Wikipedia. A zip code match could not be made for all municipalities, and this drops 7.1\% of referendums. Some municipalities match to zip codes for which there is no Zillow index, which drops $11.7 \%$ of referendums. ${ }^{14}$ I additionally restrict the sample to municipalities with four or fewer zip codes, in an effort to exclude large municipalities where the benefits may be too diffuse for impacts to be measured. This reduces the referendum sample by $15.2 \%$. Robustness checks are presented in Section 7 that vary the number of zip codes allowed, but never are large cities included. Lastly, I drop the top and bottom one percentile, which makes the effective sample range of vote margin [-22.4, 35.3]. This exclusion is intended to drop referendums that failed or passed by exceptional margins and may be abnormal in other ways. In final, the sample includes 1,145 referendums in 710 municipalities represented by 933 zip codes and a total of 15,396 zip-year observations. Because some municipalities contain more than one zip code, standard errors are clustered at the municipality level.

\footnotetext{
${ }^{13}$ Median house prices have been used frequently in hedonic studies, mostly derived from decennial census data (e.g., Chay and Greenstone 2005, Bento et al. 2015). However, some research casts doubt on the use of median prices (e.g., Gamper-Rabindran and Timmins 2013, Banzhaf and Farooque 2013) suggesting median prices may not recover statistically significant treatment effects or may estimate a treatment effect that is not representative of the whole price distribution. Coefficient estimates presented in Section 7 are statistically significant, alleviating one concern, but future research could examine distributional impacts of conservation.

${ }^{14}$ As of 2014, ZHVI covered about 10 thousand of the roughly 32 thousand zip codes in the United States. Low population zip codes are not publicly available due to accuracy concerns.
} 
I additionally collected municipal level data on construction permits from the Census Bureau. ${ }^{15}$ Specifically, these data measure the annual number of new housing units permitted. These are merged with the referendum data to form a municipal-year panel. Similar as with the housing data, I create a county level index of new construction permits and include this in regressions with permit data as the dependent variable.

I collected and calculated several zip and municipal level variables. From the 2000 Decennial Census, I gathered socioeconomic and housing variables at the municipal level. With exception of total housing units, which is used to normalize the proposed and approved referendum spending, these variables are only used to understand what types of municipalities are holding referendums and how communities that pass referendums may be different than communities in which referendums fail. Lastly, I calculated the proportion of a zip code's area that is undevelopable using GIS, 30x30 meter elevation data from USGS, and the 2001 National Land Cover Database. Following Saiz (2010), I define undevelopable as either being open water or wetland or as having a slope greater than $15 \%$.

\section{OPEN SPACE REFERENDUMS AS A QUASI-EXPERIMENT}

This paper exploits a discrete change in open space spending created by voting outcomes. For referendums with vote margins sufficiently close to the threshold, authorization of funding is as good as random. Causal inference of the effect of open space spending on housing prices assumes that municipalities with vote margins close to the threshold are similar in observable and unobservable ways. While this assumption is untestable, voting patterns can be examined for strategic behavior and observable characteristics can be compared in levels and trends to test for balance.

The top panel of Figure 2 displays the density of referendums by vote margin. Reiterating Table 1, the figure illustrates the popularity of open space referendums. While there is an increase in the frequency of observations on the positive side of the threshold, the increase is not statistically significant (McCrary p-value $=0.12$, rddensity p-value $=0.20$ ). ${ }^{16}$ While municipalities may try a second referendum if the first attempt fails, at worst this situation would fall under

\footnotetext{
${ }^{15}$ http://censtats.census.gov/bldg/bldgprmt.shtml

${ }^{16}$ See Appendix Figures A1-A4 for additional exploration of density plots and details of the McCrary and rddensity tests.
} 
what McCrary (2008) defines as partial manipulation, as each outcome is a function of thousands of votes, and will still identify unbiased estimates.

The bottom panel of Figure 2 examines how proposed funding changes by vote margin. Again, there is noise, but funding for open space and other purposes are similar on either side of the threshold (p-value is 0.192 for open space funds and 0.330 for other funds). Within $5 \%$ of the threshold, the average proposed funding for open space is $\$ 813$ and for other purposes is $\$ 324$. For other funding, there is a slight downward trend as vote margin increases, which could suggest that funding for historic preservation or public housing is less popular with voters than open space or just that places that pass open space referendums by a large margin tend to put less funding for other projects for unobservable reasons.

Table 2 presents summary statistics for the sample municipalities in terms of socioeconomic, land use, and housing characteristics. From Column 1, the average municipality has a median household income over $\$ 67,000$, has a population nearly $40 \%$ of whom have a college degree, voted over 56\% for the Democratic candidate in the 2000 presidential election, and $71 \%$ of the housing stock is owner occupied. About $19 \%$ of land is undevelopable. The average house price in the year prior to an open space referendum vote is about $\$ 291,000$ and increased 7\% since a year earlier. Since most of the sample referendums occurred during the housing boom, the $7 \%$ annual increase is reasonable. In the year prior to a vote, the average municipality approved permits to build 145 new housing units, and this was down 9 units from the year prior.

Columns 2 and 3 present means for municipalities that pass versus fail an open space referendum, respectively, and Column 4 gives the difference in means and associated standard errors. Municipalities that pass are less dense with 339 fewer people per square mile. A greater share of residents has a college degree in municipalities that pass, though incomes and political ideology are similar. Houses are worth less and there are more building permits in municipalities that pass.

Critical for the RD design, municipalities close to the threshold need to be similar. To assess this, Columns 5 and 6 test for differences in municipalities using two RD methods: Column 5 uses a global polynomial similar in the same vein as Equation (11) and Column 6 uses local linear. In contrast to the overall comparison, no municipal characteristics show any statistical discontinuity at the threshold. Most importantly, house price and new housing permit 
trends show no difference. These findings lend credence to the assumption that treatment is as good as random for municipalities that barely fail or barely pass.

\section{RESUlts}

Table 3 presents the main results from estimating Equation (11). While Equation (11) assumes that pre-referendum treatment effects are zero, this is a testable hypothesis. The results presented include three years of pre-referendum treatment effects and ten years of postreferendum treatment effects. The first column shows point estimates resulting from referendum authorized open space spending in units of \$1000 per housing unit, with standard errors shown below (clustered at the municipality level). The second column gives the same quantities for authorized funding for other purposes.

The results show that open space spending has no statistical effect on prices in the year of the referendum or any of the years preceding the referendum, but one year following prices have increased a statistically significant $0.68 \%$. For the years following, coefficients range from 0.0072 to 0.0112 , are statistically significant for all years, and trend upwards slightly. To reiterate interpretation, the coefficient on open space spending two years post referendum is 0.0074, which indicates that a municipality that barely authorizes $\$ 1000$ of open space spending per household is expected to have house prices rise $0.74 \%$ after two years relative to a municipality that barely fails to authorize open space spending, conditional on spending on other purposes and on open space spending that has happened before or after. The consistency of coefficients suggests a sustained impact of conservation, which is intuitive given the permanence of land conservation. We will return to these estimates in Section 8 when assessing efficiency, tax capitalization, and the homevoter hypothesis.

Shifting to Column 2 of Table 3, approved funding for other purposes shows no discernable effect on house prices. Coefficients flip signs often, are always insignificant, and are smaller in magnitude than the estimates for open space spending. Given the catchall nature of the "other spending” category, it is possible that these estimates are averages of multiple and offsetting effects. ${ }^{17}$

\footnotetext{
${ }^{17}$ For example, Diamond and McQuade (2016) find that affordable housing can have positive or negative spillover effects to nearby property values.
} 
The appendix presents many additional results pertaining to inclusion of various covariates, changes in vote margin sample truncation, use of local linear RD methods, as well as models that combine funding for different sources and models that do not condition on past referendums. In total, these additional results indicate robust findings and the importance of the dynamic modeling strategy that accounts for different types of funding.

\subsection{Robustness checks}

Table 4 offers a series of robustness checks that seek to bolster the main results on the capitalization of open space spending. For brevity, only the coefficients for four years post referendum are shown. The first row gives the corresponding coefficient from Table 3 for comparison purposes. Panel A varies how vote margin, the running variable, enters the specification. The second row uses only a quadratic polynomial, instead of a cubic. The third row reverts to using the cubic polynomial and additionally adds a linear function of vote margin interacted with a dummy for passage and dummies for each calendar year. This specification is meant to control for the possibility that the unobservables leading to endogeneity may be different across years. The fourth row extends this specification and uses a quadratic in vote margin interacted with dummies for each calendar year. Coefficients from all three specifications are consistent with the main results. The last row in Panel A omits vote margin as a control variable altogether, making it a difference-in-difference model. The coefficient here is about $40 \%$ smaller in magnitude and less statistically significant, which suggests that the RD design is important and the vote margin control is able to capture variation in unobservables.

Panel B reports estimates from thresholds other than $v m=0$ to show that the discontinuity in house price effects observed at $v m=0$ is not spurious. Rows 6 and 7 test whether a house price effect occurs at $v m=-10$ and $v m=10$, respectively. Neither alternative threshold shows a price effect.

Panel C examines how alternative ways of constructing the data affect results. For each row, the specification is identical to that in the main results, but each changes the maximum number of zip codes a municipality is allowed to have in order to be included in the sample. The main sample allows a maximum of four, and these specifications allow one, two and six, respectively. This changes the sample from 15,396 to 8,618, 12,048, and 17,790, respectively. The coefficients are slightly larger in magnitude for one and two zip codes, but smaller for six, 
and the $\mathrm{R}^{2} \mathrm{~s}$ decline monotonically as the number of zip codes included increases. These results could suggest that capitalization is more diffuse in larger municipalities and thus a smaller capitalization occurs for the median house.

\subsection{Assessing supply side effects}

If land slated for development is unavailable for new housing units, this could reduce the future supply of homes (relative to the counterfactual) and cause equilibrium prices to increase. Thus, the capitalization resulting from referendum-authorized open space spending may not be due to amenity valuation, but instead to supply side effects. I present two sets of results that seek to assess the degree to which the mechanism underlying the price response is a restriction in housing supply. The first test applies the logic that municipalities that are already land constrained will likely experience a greater negative supply shock and resulting price increase than municipalities that are not land constrained. Following Saiz's (2010) formulation of geographical constraints to development, I calculate the proportion of each zip code that is either open water, wetland, or sloped greater than $15 \%$. I then normalize this variable into a z-score and interact it with referendum authorized spending. If supply side effects are driving the house price response, then the sign on the interaction would be positive because spending in areas with more undevelopable land leads to a greater price increase than in areas with less undevelopable land. ${ }^{18}$

Table 5 presents results, with the first column giving the main effect of authorized open space spending and the second column giving the interaction term. The main effect coefficients are quite similar to Table 3, which is expected given that the interaction variable has mean zero, though there is some loss of precision. The coefficients on the interaction are almost all negative, a few are statistically significant, and the magnitude tends to decline over time. To aid interpretation, consider the following. Three years post referendum the average house price response to $\$ 1,000$ per housing unit of authorized referendum spending is about $0.67 \%$. For zip codes with proportion of undevelopable area one standard deviation greater than the mean, capitalization will be $0.44 \%$ less than the mean or $0.23 \%$. A zip code with undevelopable area

\footnotetext{
${ }^{18}$ Hilber and Mayer (2009) conduct a similar test with school spending and find that capitalization is greater in land constrained areas. However, in the context of RD, Calonico et al. (2016) caution against interaction with the treatment variable. Given the exploratory nature of this regression, I proceed with that caveat. For further demonstration of the explanatory power of the measure of undevelopable land, in the appendix I replicate basic results from Saiz (2010) regarding house price levels and changes.
} 
one standard deviation less than the mean has expected capitalization of $1.11 \%$. These findings do not support the hypothesis that housing supply restrictions drive capitalization, in fact they argue the opposite. One possible explanation for these results rests on a demand side story instead. Areas with lots of undevelopable land have abundant natural amenities in the way of lakes, wetlands, and hills. If there are diminishing marginal benefits of open space, then additional land preservation in these areas may yield a smaller marginal benefit than in areas with little natural impediment to development. However, the interaction coefficients do decline in magnitude over time, which suggests that price responses for areas with disparate geographies converge.

The second test switches from examining a housing price response to a construction response. I estimate Equation (11) with the log of new construction permits as the dependent variable. This variable counts each unit of housing permitted, and thus would account for changes in the types of housing (i.e., single family to multi-family) resulting from land conservation. If supply was constrained from conservation, the expected sign on the coefficients would be negative.

The results, displayed in Table 6, suggest that open space spending does not affect building permits. Coefficients are mostly positive, but do flip signs, and are never statistically significant. ${ }^{19}$ These results again suggest that a supply side effect is not driving the price response. One explanation is that municipalities are not trying to curtail development as a whole, just development in a specific place or places, possibly as part of a larger smart growth strategy. ${ }^{20}$ Alternatively, new construction could be impacted both by a supply restriction and increased demand for an area due to increased amenities, which would offset.

While neither set of results empirically supports a supply side response, neither definitively rules it out either. I proceed cautiously under the assumption that capitalization is due to amenities.

\footnotetext{
${ }^{19}$ The second column examines how funding for historic preservation, public housing and other purposes than open space impacts new construction. Interestingly, most coefficients are negative and many are statistically significant. There are several possible stories for why this may be: historic preservation may reduce the need for new construction or public housing crowds out new (non-public) construction. Again, given the catchall nature of this category, it is inappropriate to draw strong conclusions.

${ }^{20}$ Often, the referendum language identifies a specific parcel, such as "Bond for the preservation of 140 acres of farmland known as the Jones Family Farm" in Shelton, CT.
} 


\section{EFFiciency, TAX CAPitalization, AND THE HoMeVoter Hypothesis}

From Section 2, the test of efficient provision of local public goods hinges on the sign of capitalization. The empirical models in this paper are designed to test how exogenous increases in spending on local land conservation affect housing prices, which capitalize the benefits of conservation and the necessary tax increases. The main results in Section 7.1 suggest a positive and statistically significant house price response, which indicates that the provision of local open space conservation is inefficient and underprovided. One additional assumption needed for this conclusion is that the median house value capitalization is representative of the average. While median prices were used by Oates (1969) and Brueckner (1979), Brueckner (1982) makes clear that a true test of efficiency requires aggregate or average housing values. In the particular context of land conservation, median capitalization may be attenuated from the average because the median is unlikely to capture price change of houses proximate to conserved land, which are likely the largest. ${ }^{21}$

The test of tax capitalization asserted that capitalization should increase annually at the rate that the future tax burden declines. Table 3 indicated increasing coefficients, consistent with that assertion. For further investigation, Figure 3 displays estimated dollar values of capitalization resulting from Table 3 for years 1-10 following a referendum, assuming mean values of conservation spending (\$813 per housing unit) and housing values $(\$ 282,383)$ near the threshold. The pattern is generally increasing and a simple linear regression of capitalization on year yields a slope of 103.99 (std. err. $=23.33, \mathrm{R}^{2}=0.71$ ). Under the premise of perfect tax capitalization, the estimated slope would imply that the future tax burden declines by $\$ 104$ per year. The LandVote data do not contain detailed information on funding structures such as term lengths for bonds or expiration dates for tax increases, thus the \$104 per year cannot be validated. However, to give a sense of magnitude, a 10-year bond for \$813 per housing unit with a 5\% interest rate, both of which are reasonable for a municipal bond, would average an \$81.30 per year reduction in future tax burden. ${ }^{22}$ Thus, the annual increase in capitalization seems a bit

\footnotetext{
${ }^{21}$ Additional support comes from Gamper-Rabindran and Timmins (2013), who examine how housing prices respond to superfund remediation across the whole price distribution. Their results suggest that the median price impact is similar to the average impact, but is slightly attenuated because of larger impacts that occur at one tail. ${ }^{22}$ Calculation details available in the appendix.
} 
larger than expected. Possible conflating factors are delays in spending or benefits that exceed expectations. However, on the whole, the empirical findings strongly support tax capitalization.

The test of the homevoter hypothesis stated that homeowners will vote in accordance with efficiency impacts of the referendum. To judge this prediction, we must examine the capitalization effects of passage of the whole referendum, not just the portion for open space. Appendix Table A5 presents results from a model that only uses a binary passage variable as the key independent variable (Equation 9) and does not split funding between open space and other purposes. The results suggest passage has no statistical effect on housing prices - coefficients are all statistical zeros and flip signs. Given these findings, homeowners should be indifferent between voting yes or no. Given that a RD design was used, the estimates are only valid around the threshold, where voters are indeed indifferent. Thus, the results support the homevoter hypothesis. This conclusion rests on two assumptions. First, the median voter is a homeowner, which seems reasonable given that sample towns are comprised of $71.5 \%$ owners. Second, the median voter experiences a similar property value response as the median house, which was also necessary for tax capitalization and discussed in the prior paragraph.

\section{ConClusion}

There are essentially two ways for citizens to register their demand for local public goods, voting and residential choice. This paper incorporates both means of demand revelation in the context municipal open space referendums, which are a popular means to permanently preserve undeveloped land. My primary focus is to assess the efficiency of local open space provision. Using a dynamic $\mathrm{RD}$ research design based on referendum outcomes, I estimate that housing prices increase about $0.68-1.12 \%$ for every $\$ 1000$ per household of referendum approved open space spending. This finding indicates that households value land conservation more than the additional cost of taxes, and thus efficiency increases when open space spending increases. However, drawing on the intuitive findings of prior open space valuation literature, there are almost certainly within-municipality differences in benefits based on proximity to conserved lands, and perhaps characteristics such as income as well. Future research that can integrate municipality-wide efficiency aims, as well as distributional impacts, would be most valuable for efficient and equitable policy decisions. 
The main capitalization results suggest that residential choice is not leading to efficient provision of local open space. Returning to the idea that there are two ways to register demand, the results can also be used to evaluate whether voting guides municipalities to efficient outcomes. The findings of this paper suggest that there are substantial net benefits for current residents from referendum authorized municipal open space spending. However, these open space referendums are frequently combined with spending on other purposes, such as affordable housing and historic preservation, and results also suggest that passage of a referendum in its totality does not increase efficiency. This raises additional questions for future research about why various objectives are combined in a single referendum and how the political process affects the efficient provision of local public goods.

\section{REFERENCES}

Abbott, J. K., \& Klaiber, H. A. (2011). An embarrassment of riches: Confronting omitted variable bias and multi-scale capitalization in hedonic price models. Review of Economics and Statistics, 93(4), 1331-1342.

Ahlfeldt, G. M., \& Maennig, W. (2015). Homevoters vs. leasevoters: A spatial analysis of airport effects. Journal of Urban Economics, 87, 85-99.

Albouy, D. (2013). Partisan representation in Congress and the geographic distribution of Federal funds. Review of Economics and Statistics, 95(1), 127-141.

Altonji, M., Lang, C., \& Puggioni, G. (2016). Can urban areas help sustain the preservation of open space? Evidence from statewide referenda. Ecological Economics, 130, 82-91.

Anderson, S. T., \& West, S. E. (2006). Open space, residential property values, and spatial context. Regional Science and Urban Economics, 36(6), 773-789.

Ballotpedia. https://ballotpedia.org. Accessed May 10, 2016.

Balsdon, E. M. (2012). Property Value Capitalization and Municipal Open Space Referendums. Land Economics, 88(2), 201-232.

Banzhaf, H. S., \& Farooque, O. (2013). Interjurisdictional housing prices and spatial amenities: Which measures of housing prices reflect local public goods?. Regional Science and Urban Economics, 43(4), 635-648.

Banzhaf, H. S., Oates, W. E., \& Sanchirico, J. N. (2010). Success and design of local referenda for land conservation. Journal of Policy Analysis and Management, 29(4), 769-798.

Barrow, L., \& Rouse, C. E. (2004). Using market valuation to assess public school spending. Journal of Public Economics, 88(9), 1747-1769. 
Bayer, P., \& McMillan, R. (2012). Tiebout sorting and neighborhood stratification. Journal of Public Economics, 96(11), 1129-1143.

Bento, A., Freedman, M., \& Lang, C. (2015). Who benefits from environmental regulation? evidence from the clean air act amendments. Review of Economics and Statistics, 97(3), 610622.

Bruce, Andrew. (2014). Zillow Home Value Index: Methodology. Zillow Real Estate Research. http://www.zillow.com/research/zhvi-methodology-6032/ (accessed 11/11/2015).

Brueckner, J. K. (1979). Property values, local public expenditure and economic efficiency. Journal of public economics, 11(2), 223-245.

Brueckner, J. K. (1982). A test for allocative efficiency in the local public sector. Journal of public Economics, 19(3), 311-331.

Burkhardt, J., \& Chan, N. W. (2017). The dollars and sense of ballot propositions: estimating willingness to pay for public goods using aggregate voting data. Journal of the Association of Environmental and Resource Economists, 4(2), 479-503.

Calonico, S., Cattaneo, M. D., \& Titiunik, R. (2014). Robust nonparametric confidence intervals for regression-discontinuity designs. Econometrica, 82(6), 2295-2326.

Calonico, S., Cattaneo, M. D., Farrell, M. H., \& Titiunik, R. (2016). Regression discontinuity designs using covariates. URL http://www-personal. umich. edu/ cattaneo/papers/CalonicoCattaneo-/Farrell-Titiunik_2016_wp. pdf.

Caplan, B. (2001). Standing Tiebout on his head: Tax capitalization and the monopoly power of local governments. Public Choice, 108(1), 101-122.

Caughey, D., \& Sekhon, J. S. (2011). Elections and the regression discontinuity design: Lessons from close US house races, 1942-2008. Political Analysis, 19(4), 385-408.

Cellini, S. R., Ferreira, F., \& Rothstein, J. (2010). The value of school facility investments: Evidence from a dynamic regression discontinuity design. The Quarterly Journal of Economics, 125(1), 215-261.

Chay, K. Y., \& Greenstone, M. (2005). Does air quality matter? Evidence from the housing market. Journal of political Economy, 113(2), 376-424.

Coate, S. (2013). Evaluating durable public good provision using housing prices (No. w18767). National Bureau of Economic Research.

Deacon, R., \& Shapiro, P. (1975). Private preference for collective goods revealed through voting on referenda. The American Economic Review, 943-955.

Dehring, C. A., Depken, C. A., \& Ward, M. R. (2008). A direct test of the homevoter hypothesis. Journal of Urban Economics, 64(1), 155-170.

Diamond, R., \& McQuade, T. (2016). Who wants affordable housing in their backyard? An equilibrium analysis of low income property development (No. w22204). National Bureau of Economic Research.

Do, A. Q., \& Sirmans, C. F. (1994). Residential property tax capitalization: discount rate evidence from California. National Tax Journal, 341-348. 
Eggers, A. C., Fowler, A., Hainmueller, J., Hall, A. B., \& Snyder, J. M. (2015). On the validity of the regression discontinuity design for estimating electoral effects: New evidence from over 40,000 close races. American Journal of Political Science, 59(1), 259-274.

Fischel, W. A. (2001). The homevoter hypothesis: How home values influence local government taxation, school finance, and land-use policies. Cambridge, MA: Harvard University Press.

Gamper-Rabindran, S., \& Timmins, C. (2013). Does cleanup of hazardous waste sites raise housing values? Evidence of spatially localized benefits. Journal of Environmental Economics and Management, 65(3), 345-360.

Heintzelman, M. D. (2010). The value of land use patterns and preservation policies. The BE Journal of Economic Analysis \& Policy, 10(1).

Heintzelman, M. D., Walsh, P. J., \& Grzeskowiak, D. J. (2013). Explaining the appearance and success of open space referenda. Ecological economics, 95, 108-117.

Hilber, C. A. L., \& Mayer, C. (2009). Why do households without children support local public schools? Linking house price capitalization to school spending. Journal of Urban Economics, 65(1), 74-90.

Hobbs, F., \& Stoops, N. (2002). Demographic trends in the 20th century (Vol. 4). US Census Bureau.

Huang, H., \& Tang, Y. (2012). Residential land use regulation and the US housing price cycle between 2000 and 2009. Journal of Urban Economics, 71(1), 93-99.

Irwin, E. G. (2002). The effects of open space on residential property values. Land economics, 78(4), 465-480.

Isen, A. (2014). Do local government fiscal spillovers exist? Evidence from counties, municipalities, and school districts. Journal of Public Economics, 110, 57-73.

Jerch, R., Kahn, M. E., \& Li, S. (2017). The efficiency of local government: The role of privatization and public sector unions. Journal of Public Economics, 154, 95-121.

Kotchen, M. J., \& Powers, S. M. (2006). Explaining the appearance and success of voter referenda for open-space conservation. Journal of Environmental Economics and Management, 52(1), 373-390.

Kroetz, K., Sanchirico, J. N., Armsworth, P. R., \& Spencer Banzhaf, H. (2014). Benefits of the ballot box for species conservation. Ecology letters, 17(3), 294-302.

Kuminoff, N. V., \& Pope, J. C. (2014). Do “Capitalization Effects” for Public Goods Reveal the Public's Willingness to Pay?. International Economic Review, 55(4), 1227-1250.

Legislative Analyst’s Office. (2014). A Look at Voter-Approval Requirements for Local Taxes. Available at http://www.lao.ca.gov/Publications/Detail/2978.

Lee, D. S. (2008). Randomized experiments from non-random selection in US House elections. Journal of Econometrics, 142(2), 675-697.

Lee, D. S., Moretti, E., \& Butler, M. J. (2004). Do voters affect or elect policies? Evidence from the US House. The Quarterly Journal of Economics, 119(3), 807-859.

Martorell, P., Stange, K., \& McFarlin, I. (2016). Investing in schools: capital spending, facility conditions, and student achievement. Journal of Public Economics, 140, 13-29. 
McCrary, J. (2008). Manipulation of the running variable in the regression discontinuity design: A density test. Journal of econometrics, 142(2), 698-714.

McConnell, V., \& Walls, M. A. (2005). The value of open space: Evidence from studies of nonmarket benefits (pp. 1-78). Washington, DC: Resources for the Future.

Nelson, E., Uwasu, M., \& Polasky, S. (2007). Voting on open space: What explains the appearance and support of municipal-level open space conservation referenda in the United States?. Ecological Economics, 62(3), 580-593.

Oates, W. E. (1969). The effects of property taxes and local public spending on property values: An empirical study of tax capitalization and the Tiebout hypothesis. Journal of political economy, 77(6), 957-971.

Palmon, O., \& Smith, B. A. (1998). New evidence on property tax capitalization. Journal of Political Economy, 106(5), 1099-1111.

Rhode Island Board of Elections. Previous Election Results. http://www.elections.state.ri.us/elections/preresults/. Accessed May 31, 2016.

Ross, S., \& Yinger, J. (1999). Sorting and voting: A review of the literature on urban public finance. Handbook of regional and urban economics, 3, 2001-2060.

Saiz, A. (2010). The Geographic Determinants of Housing Supply. The Quarterly Journal of Economics, 125(3), 1253-1296.

Solé-Ollé, A., \& Viladecans-Marsal, E. (2013). Do political parties matter for local land use policies?. Journal of Urban Economics, 78, 42-56.

Sonstelie, J. C., \& Portney, P. R. (1980). Take the money and run: a theory of voting in local referenda. Journal of Urban Economics, 8(2), 187-195.

The Trust for Public Land, Land Vote Database. www.landvote.org . Accessed May 21, 2013.

Tiebout, C. M. (1956). A pure theory of local expenditures. Journal of political economy, 64(5), 416-424.

Weber, J. G., Burnett, J., \& Xiarchos, I. M. (2016). Broadening benefits from natural resource extraction: Housing values and taxation of natural gas wells as property. Journal of Policy Analysis and Management, 35(3), 587-614.

U.S. Forest Service. (2016). Open space conservation. http://www.fs.fed.us/openspace/. Accessed May 31, 2016.

Yinger, J. (1985). Inefficiency and the median voter: property taxes, capitalization, heterogeneity, and the theory of the second best. Perspectives on local public finance and public policy, 2(3), 3-30. 


\section{Figures and Tables}

Figure 1: Illustration of spatial distribution of open space referendums overlaying population density using Minneapolis-St. Paul

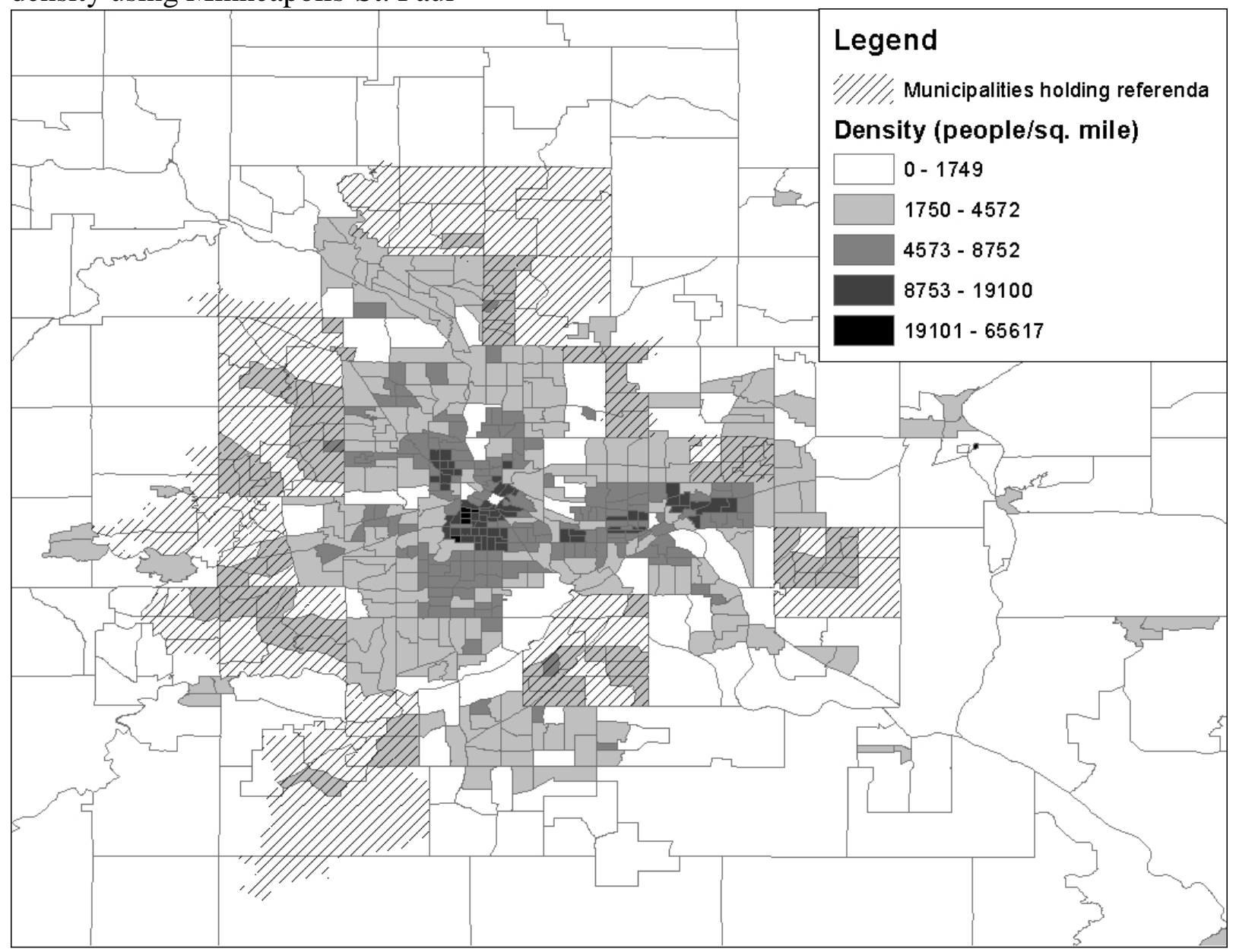


Figure 2: Distribution of sample referendums and proposed funding by vote margin
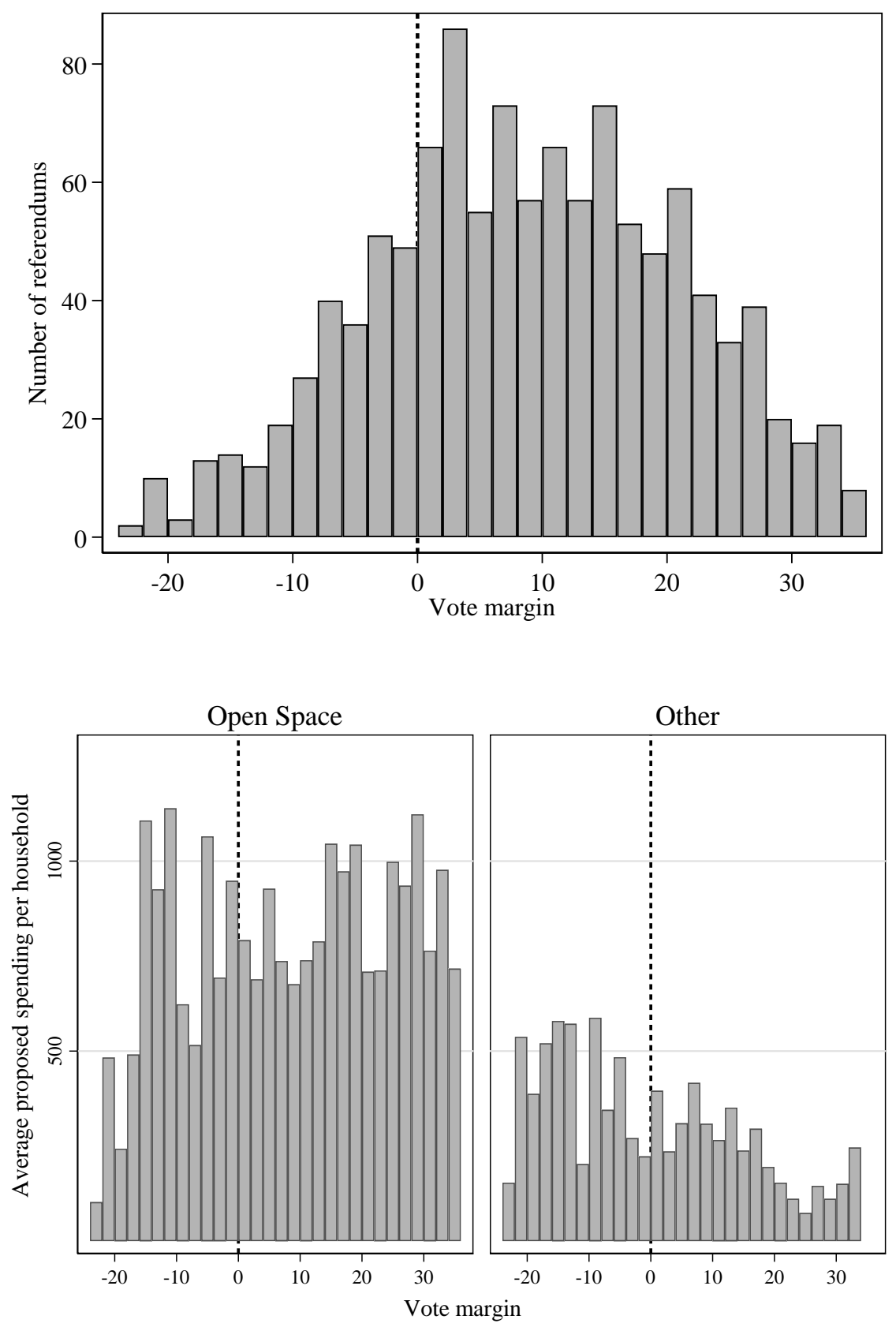

Notes: Figure includes only those open space referendums in the main sample, which includes all years 1988-2012, excludes those with a vote margin less than -20 or exceeding 35, and excludes referendums that match to zip codes lacking house price data or that match to municipalities with greater than 4 zip codes. Vote margin equals the percent of yes votes minus the percent needed to pass. Referendums are grouped by vote margins in bins of $2 \%$. Proposed spending is split by funds allocated for open space preservation and those allocated for other purposes, such as public housing and historic preservation. 
Figure 3: Capitalization trends following referendum

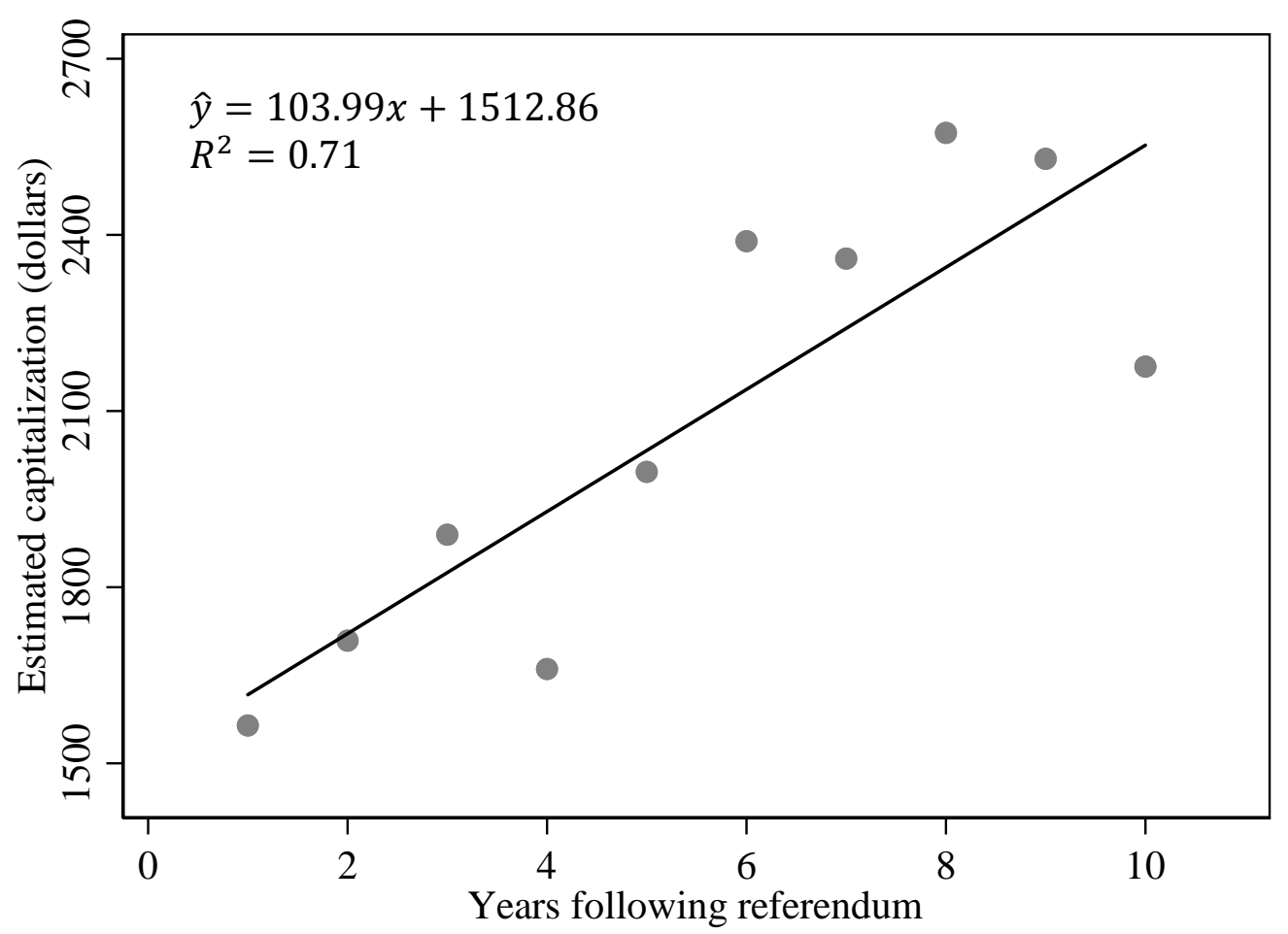

Notes: Estimated capitalization is the product of the average house price for municipalities passing an open space referendum with a vote margin less than $5 \%(\$ 282,383.0)$ and the corresponding coefficient for years 1-10 from Table 3, scaled by the size of the average referendum within $5 \%$ of the threshold ( $\$ 812.8$ per household). The standard error for the slope coefficient is 23.33 and the t-statistic is 4.46 . 
Table 1: Open space referendum summary statistics

\begin{tabular}{|c|c|c|c|c|c|c|}
\hline $\begin{array}{c}\text { Year } \\
\text { (1) }\end{array}$ & $\begin{array}{l}\text { Number of } \\
\text { referendums } \\
\text { (2) }\end{array}$ & $\begin{array}{c}\text { Avg. } \\
\text { amount } \\
\text { proposed } \\
\text { per house } \\
\text { unit (\$) } \\
(3)\end{array}$ & $\begin{array}{l}\text { Fraction of } \\
\text { proposed } \\
\text { funds } \\
\text { dedicated to } \\
\text { open space } \\
\text { (4) }\end{array}$ & $\begin{array}{l}\text { Fraction that } \\
\text { held previous } \\
\text { referendum } \\
\text { (5) }\end{array}$ & $\begin{array}{c}\text { Fraction } \\
\text { approved } \\
\text { (6) }\end{array}$ & $\begin{array}{l}\text { Average } \\
\text { vote } \\
\text { margin } \\
(7)\end{array}$ \\
\hline 1988 & 13 & 385 & 0.85 & 0.00 & 0.92 & 13.39 \\
\hline 1989 & 8 & 1,254 & 0.98 & 0.13 & 0.75 & 6.04 \\
\hline 1990 & 11 & 436 & 0.97 & 0.18 & 0.73 & 8.19 \\
\hline 1991 & 2 & 649 & 0.92 & 0.00 & 0.50 & -0.23 \\
\hline 1992 & 12 & 399 & 0.93 & 0.00 & 0.75 & 7.39 \\
\hline 1993 & 12 & 601 & 0.97 & 0.17 & 0.75 & 7.33 \\
\hline 1994 & 13 & 704 & 0.92 & 0.38 & 0.85 & 11.43 \\
\hline 1995 & 16 & 876 & 0.79 & 0.19 & 0.69 & 9.79 \\
\hline 1996 & 37 & 869 & 0.81 & 0.24 & 0.73 & 8.95 \\
\hline 1997 & 33 & 1,295 & 0.87 & 0.21 & 0.94 & 12.36 \\
\hline 1998 & 92 & 863 & 0.77 & 0.14 & 0.86 & 12.13 \\
\hline 1999 & 53 & 1,057 & 0.89 & 0.28 & 0.91 & 14.80 \\
\hline 2000 & 119 & 1,250 & 0.55 & 0.19 & 0.79 & 9.69 \\
\hline 2001 & 111 & 923 & 0.68 & 0.28 & 0.68 & 6.39 \\
\hline 2002 & 73 & 1,015 & 0.76 & 0.49 & 0.78 & 10.92 \\
\hline 2003 & 77 & 1,117 & 0.83 & 0.43 & 0.75 & 8.03 \\
\hline 2004 & 113 & 1,371 & 0.71 & 0.50 & 0.82 & 10.24 \\
\hline 2005 & 67 & 1,369 & 0.77 & 0.58 & 0.69 & 4.89 \\
\hline 2006 & 90 & 1,582 & 0.80 & 0.46 & 0.74 & 6.70 \\
\hline 2007 & 52 & 1,239 & 0.78 & 0.54 & 0.60 & 6.99 \\
\hline 2008 & 44 & 1,285 & 0.78 & 0.61 & 0.68 & 6.64 \\
\hline 2009 & 25 & 1,151 & 0.64 & 0.68 & 0.60 & 5.18 \\
\hline 2010 & 18 & 892 & 0.67 & 0.72 & 0.72 & 4.79 \\
\hline 2011 & 19 & 1,484 & 0.73 & 0.74 & 0.58 & 6.01 \\
\hline 2012 & 35 & 992 & 0.65 & 0.66 & 0.74 & 7.62 \\
\hline Mean & 45.8 & 1,132 & 0.75 & 0.38 & 0.76 & 8.78 \\
\hline
\end{tabular}

Notes: Data obtained from TPL Land Vote Database. Dollar amounts are normalized by the number of housing units within a given municipality, which were obtained from the 2000 Decennial Census. Vote margin equals the proportion of yes votes minus the proportion needed to pass. 
Table 2: Municipality descriptive statistics and pre-referendum balance of treatment and control groups

\begin{tabular}{|c|c|c|c|c|c|c|}
\hline & $\begin{array}{c}\text { All } \\
\text { municipalities } \\
(1) \\
\end{array}$ & $\begin{array}{c}\text { Municipalities that } \\
\text { ever fail a referendum } \\
(2)\end{array}$ & $\begin{array}{c}\text { Municipalities that } \\
\text { ever pass a referendum } \\
\text { (3) }\end{array}$ & $\begin{array}{l}\text { Difference in } \\
\text { means } \\
(4)\end{array}$ & $\begin{array}{c}\text { Difference } \\
\text { Global RD } \\
\text { (5) }\end{array}$ & $\begin{array}{c}\text { Difference } \\
\text { Local RD } \\
(6) \\
\end{array}$ \\
\hline \multicolumn{7}{|l|}{ A. Socioeconomic variables } \\
\hline Total Population & $\begin{array}{c}24954.5 \\
(36338.1)\end{array}$ & $\begin{array}{c}24620.4 \\
(35271.6)\end{array}$ & $\begin{array}{c}25061.1 \\
(36691.2)\end{array}$ & $\begin{array}{c}440.7 \\
(2508.7)\end{array}$ & $\begin{array}{c}9554.8 \\
(7939.3)\end{array}$ & $\begin{array}{c}8370.3 \\
(5839.5)\end{array}$ \\
\hline Population density (per sq. mile) & $\begin{array}{c}1501.1 \\
(1806.2)\end{array}$ & $\begin{array}{c}1758.2 \\
(2000.9)\end{array}$ & $\begin{array}{c}1419.0 \\
(1732.6)\end{array}$ & $\begin{array}{c}-339.1 \\
(124.3)^{* * *}\end{array}$ & $\begin{array}{c}369.7 \\
(393.3)\end{array}$ & $\begin{array}{c}221.6 \\
(434.1)\end{array}$ \\
\hline Median household income (\$) & $\begin{array}{c}67048.7 \\
(21987.6)\end{array}$ & $\begin{array}{c}65535.3 \\
(20245.9)\end{array}$ & $\begin{array}{c}67531.6 \\
(22504.8)\end{array}$ & $\begin{array}{c}1996.3 \\
(1516.8)\end{array}$ & $\begin{array}{l}-3112.1 \\
(4812.8)\end{array}$ & $\begin{array}{l}-3792.5 \\
(6089.7)\end{array}$ \\
\hline Owner occupied housing (\%) & $\begin{array}{c}71.47 \\
(16.06)\end{array}$ & $\begin{array}{c}72.01 \\
(14.94)\end{array}$ & $\begin{array}{c}71.30 \\
(16.40)\end{array}$ & $\begin{array}{l}-0.71 \\
(1.11)\end{array}$ & $\begin{array}{l}-3.53 \\
(3.52)\end{array}$ & $\begin{array}{l}-2.96 \\
(4.19)\end{array}$ \\
\hline College or more (\%) & $\begin{array}{c}39.98 \\
(15.04)\end{array}$ & $\begin{array}{c}37.33 \\
(14.26)\end{array}$ & $\begin{array}{c}40.83 \\
(15.19)\end{array}$ & $\begin{array}{c}3.50 \\
(1.03)^{* * *}\end{array}$ & $\begin{array}{l}-1.26 \\
(3.26)\end{array}$ & $\begin{array}{l}-2.45 \\
(4.02)\end{array}$ \\
\hline Democrat (\%) & $\begin{array}{l}55.63 \\
(9.61)\end{array}$ & $\begin{array}{l}56.14 \\
(9.60)\end{array}$ & $\begin{array}{l}55.47 \\
(9.61)\end{array}$ & $\begin{array}{l}-0.67 \\
(0.66)\end{array}$ & $\begin{array}{c}0.81 \\
(2.11)\end{array}$ & $\begin{array}{c}2.78 \\
(2.82)\end{array}$ \\
\hline \multicolumn{7}{|l|}{ B. Land use data } \\
\hline$\%$ undevelopable & $\begin{array}{c}19.12 \\
(16.16)\end{array}$ & $\begin{array}{c}20.15 \\
(17.76)\end{array}$ & $\begin{array}{c}18.80 \\
(15.61)\end{array}$ & $\begin{array}{l}-1.35 \\
(1.12)\end{array}$ & $\begin{array}{c}3.70 \\
(3.53)\end{array}$ & $\begin{array}{c}2.30 \\
(4.40)\end{array}$ \\
\hline \multicolumn{7}{|l|}{ C. Housing data } \\
\hline House prices $(\mathrm{t}-1)$ & $\begin{array}{c}291208.1 \\
(183154.5)\end{array}$ & $\begin{array}{c}308095.1 \\
(187171.5)\end{array}$ & $\begin{array}{c}285507.6 \\
(181557.9)\end{array}$ & $\begin{array}{c}-22587.6 \\
(13689.3)^{*}\end{array}$ & $\begin{array}{c}24601.0 \\
(43178.6)\end{array}$ & $\begin{array}{c}11838.9 \\
(43681.0)\end{array}$ \\
\hline Change in house prices (\%) & $\begin{array}{c}0.07 \\
(0.08)\end{array}$ & $\begin{array}{c}0.08 \\
(0.08)\end{array}$ & $\begin{array}{c}0.07 \\
(0.08)\end{array}$ & $\begin{array}{c}0.00 \\
(0.01)\end{array}$ & $\begin{array}{c}0.00 \\
(0.02)\end{array}$ & $\begin{array}{c}0.01 \\
(0.03)\end{array}$ \\
\hline New housing permits (t-1) & $\begin{array}{c}145.02 \\
(277.05)\end{array}$ & $\begin{array}{c}109.85 \\
(206.48)\end{array}$ & $\begin{array}{c}156.53 \\
(295.75)\end{array}$ & $\begin{array}{c}46.69 \\
(21.72)^{* *}\end{array}$ & $\begin{array}{l}100.16 \\
(66.53)\end{array}$ & $\begin{array}{c}79.98 \\
(74.86)\end{array}$ \\
\hline Change in permits (t-1)-(t-2) & $\begin{array}{c}-9.41 \\
(148.34) \\
\end{array}$ & $\begin{array}{c}-14.04 \\
(186.97) \\
\end{array}$ & $\begin{array}{c}-7.83 \\
(132.72) \\
\end{array}$ & $\begin{array}{c}6.20 \\
(12.38) \\
\end{array}$ & $\begin{array}{c}-36.93 \\
(38.84)\end{array}$ & $\begin{array}{c}-43.69 \\
(36.59)\end{array}$ \\
\hline
\end{tabular}

Notes: Columns 1-3 present means and standard deviations in parentheses. Columns 4-6 present estimated differences in means and standard errors. The

regressions leading to Column 5 control for a cubic polynomial in vote margin interacted with an indicator for pass. Column 6 applies the estimator developed by Calonico et al. (2014). Socioeconomic data come from the 2000 Decennial Census. Democrat vote share is at the county level and comes from the 2000 election.

$\%$ undevelopable is the proportion of area within a zip code's boundary that is either open water or wetland or has slope greater than $15 \%$. Open water and wetland data come the National Land Cover Database and slope was calculated from 30x30 meter digital elevation data from USGS. House prices come from the Zillow all home index. New building permit data are from the Census Bureau. For house prices and permits, t- 1 refers to the year before a referendum is held and $\mathrm{t}-2$ is two years before. 
Table 3: The effect of authorized referendum spending on log housing prices

\begin{tabular}{|c|c|c|}
\hline & \multicolumn{2}{|c|}{$\$ 1000$ per housing unit in: } \\
\hline & $\begin{array}{l}\text { Open space funding } \\
\text { (1) }\end{array}$ & $\begin{array}{l}\text { Other funding } \\
\text { (2) }\end{array}$ \\
\hline \multirow[t]{2}{*}{3 years prior } & -0.0008 & 0.0008 \\
\hline & $(0.0022)$ & $(0.0017)$ \\
\hline \multirow[t]{2}{*}{2 years prior } & 0.0015 & 0.0020 \\
\hline & $(0.0026)$ & $(0.0016)$ \\
\hline \multirow[t]{2}{*}{1 year prior } & 0.0036 & -0.0001 \\
\hline & $(0.0027)$ & $(0.0017)$ \\
\hline \multirow[t]{2}{*}{ Year of referendum } & 0.0044 & 0.0010 \\
\hline & $(0.0032)$ & $(0.0017)$ \\
\hline \multirow[t]{2}{*}{1 year later } & 0.0068 & 0.0004 \\
\hline & $(0.0027)^{* *}$ & $(0.0018)$ \\
\hline \multirow[t]{2}{*}{2 years later } & 0.0074 & 0.0013 \\
\hline & $(0.0025) * * *$ & $(0.0018)$ \\
\hline \multirow[t]{2}{*}{3 years later } & 0.0082 & -0.0006 \\
\hline & $(0.0026) * * *$ & $(0.0018)$ \\
\hline \multirow[t]{2}{*}{4 years later } & 0.0072 & -0.0006 \\
\hline & $(0.0028) * * *$ & $(0.0021)$ \\
\hline \multirow[t]{2}{*}{5 years later } & 0.0087 & 0.0009 \\
\hline & $(0.0031) * * *$ & (0.0019) \\
\hline \multirow[t]{2}{*}{6 years later } & 0.0104 & -0.0005 \\
\hline & $(0.0030) * * *$ & (0.0019) \\
\hline \multirow[t]{2}{*}{7 years later } & 0.0103 & -0.0007 \\
\hline & $(0.0032) * * *$ & $(0.0019)$ \\
\hline \multirow[t]{2}{*}{8 years later } & 0.0112 & -0.0009 \\
\hline & $(0.0025) * * *$ & $(0.0018)$ \\
\hline \multirow[t]{2}{*}{9 years later } & 0.0110 & -0.0016 \\
\hline & $(0.0026) * * *$ & $(0.0021)$ \\
\hline \multirow[t]{2}{*}{10 years later } & 0.0095 & 0.0006 \\
\hline & $(0.0043)^{* *}$ & $(0.0014)$ \\
\hline
\end{tabular}

Notes: Results shown are from a single regression. The specification follows Equation (11) with the dependent variable being the log of the Zillow all home index, the key independent variables being referendum authorized spending per housing unit (split by funding for open space and funding for other purposes) interacted with three lead years, the year of the referendum, and 10 lag years. Controls include a third order polynomial in vote margin interacted with an indicator for passage and interacted with all lead and lag years, an indicator variable for the presence of a referendum interacted with all lead and lag years, proposed funding amounts interacted with all lead and lag years, year by census division fixed effects, a county level annual price index, and zip code fixed effects. The number of zip-year observations is 15,396 and the $\mathrm{R}^{2}$ is 0.992 . Standard errors are shown in parentheses and are estimated using the Eicker-White formula to correct for heteroskedasticity and are clustered at the municipality level. *, **, and *** indicate significance at $10 \%, 5 \%$, and $1 \%$, respectively. 
Table 4: Alternative specifications for the effect of referendum spending

\begin{tabular}{lc}
\hline \hline & $\begin{array}{c}\text { Effect of \$1000 of open } \\
\text { space funding approved } \\
\text { on log house prices } 4 \\
\text { years after referendum }\end{array}$ \\
\hline Baseline (from Table 3) & 0.0072 \\
A. Alternative specifications & $(0.0028)^{* * *}$ \\
\hline Quadratic & 0.0080 \\
Linear x year interaction & $(0.0028)^{* * *}$ \\
Quadratic x year interaction & 0.0072 \\
Difference-in-difference & $(0.0028)^{* * *}$ \\
B. Placebo thresholds & 0.0072 \\
\hline Actual threshold minus 10 & $(0.0028)^{* * *}$ \\
Actual threshold plus 10 & 0.0044 \\
& $(0.0024)^{*}$ \\
C. Alternative data construction & -0.0031 \\
\hline Municipalities containing one zip code & $(0.0040)$ \\
Municipalities containing two or fewer zip codes & -0.0015 \\
Municipalities containing six or fewer zip codes & $(0.0058)$ \\
\hline
\end{tabular}

Notes: Each coefficient comes from a separate regression. The first row replicates the main results from Table 3. The second row uses only a quadratic polynomial in vote margin, instead of a cubic. The third row reverts to using the cubic polynomial and additionally adds a linear function of vote margin interacted with dummies for each calendar year and a dummy for passage. The fourth row extends this specification and uses a quadratic in vote margin interacted with dummies for each calendar year. Row 5 is a difference-in-difference specification that excludes any function of vote margin. Rows 6 and 7 test whether a house price effect occurs at vm=-10 and vm=10, respectively. In both specifications, the main effect at vm $=0$ is still included. For each model in Panel C, the specification is identical to that in the main results. Rows 8-10 change the maximum allowable zip codes a municipality is allowed to have in order to be included in the sample to one, two and six, respectively. The sample size for these rows are $8,618,12,048$, and 17,790 , and the $\mathrm{R}^{2} \mathrm{~s}$ are 0.9930 , 0.9924, and 0.9917, respectively. 
Table 5: Heterogeneity in house price response due to undevelopable land

\begin{tabular}{|c|c|c|}
\hline & \multicolumn{2}{|c|}{$\begin{array}{c}\text { Effect of } \$ 1,000 \text { per housing unit in open space } \\
\text { spending }\end{array}$} \\
\hline & Main effect & $\begin{array}{c}\text { Interacted with \% } \\
\text { undevelopable (z-score) }\end{array}$ \\
\hline \multirow[t]{2}{*}{3 years prior } & -0.0010 & -0.0003 \\
\hline & $(0.0036)$ & $(0.0030)$ \\
\hline \multirow[t]{2}{*}{2 years prior } & 0.0013 & 0.0005 \\
\hline & $(0.0033)$ & $(0.0027)$ \\
\hline \multirow[t]{2}{*}{1 year prior } & 0.0041 & -0.0029 \\
\hline & $(0.0034)$ & $(0.0028)$ \\
\hline \multirow[t]{2}{*}{ Year of referendum } & 0.0041 & -0.0064 \\
\hline & $(0.0037)$ & $(0.0030)^{* *}$ \\
\hline \multirow[t]{2}{*}{1 year later } & 0.0059 & -0.0060 \\
\hline & $(0.0035)^{*}$ & $(0.0030)^{* *}$ \\
\hline \multirow[t]{2}{*}{2 years later } & 0.0057 & -0.0049 \\
\hline & $(0.0033)^{*}$ & $(0.0030)$ \\
\hline \multirow[t]{2}{*}{3 years later } & 0.0067 & -0.0044 \\
\hline & $(0.0031)^{* *}$ & $(0.0027)$ \\
\hline \multirow[t]{2}{*}{4 years later } & 0.0075 & -0.0024 \\
\hline & $(0.0032)^{* *}$ & $(0.0025)$ \\
\hline \multirow[t]{2}{*}{5 years later } & 0.0072 & -0.0054 \\
\hline & $(0.0034)^{* *}$ & $(0.0026)^{* *}$ \\
\hline \multirow[t]{2}{*}{6 years later } & 0.0098 & -0.0030 \\
\hline & $(0.0036)^{* * *}$ & $(0.0028)$ \\
\hline \multirow[t]{2}{*}{7 years later } & 0.0091 & -0.0043 \\
\hline & $(0.0040)^{* *}$ & $(0.0037)$ \\
\hline \multirow[t]{2}{*}{8 years later } & 0.0102 & -0.0005 \\
\hline & $(0.0035) * * *$ & $(0.0031)$ \\
\hline \multirow[t]{2}{*}{9 years later } & 0.0113 & 0.0015 \\
\hline & $(0.0036) * * *$ & $(0.0030)$ \\
\hline \multirow[t]{2}{*}{10 years later } & 0.0070 & -0.0002 \\
\hline & $(0.0047)$ & $(0.0038)$ \\
\hline
\end{tabular}

Notes: Results shown are from a single regression. Specification is identical to that shown in Table 3, except that the percentage of undevelopable area in a zip code (transformed into a z-score) is interacted with authorized open space and other spending and proposed open space and other spending. The zipyear sample is identical to Table 3 and the $\mathrm{R}^{2}$ is 0.992 . See Table 3 for more details. 
Table 6: The effect of referendum spending on log construction permits

\begin{tabular}{|c|c|c|}
\hline & $\$ 1000$ pe & anit in: \\
\hline & $\begin{array}{l}\text { Open space funding } \\
\text { (1) }\end{array}$ & $\begin{array}{l}\text { Other funding } \\
\text { (2) }\end{array}$ \\
\hline 3 years prior & 0.0654 & 0.0038 \\
\hline & $(0.0508)$ & $(0.0159)$ \\
\hline 2 years prior & 0.0002 & -0.0039 \\
\hline & $(0.0540)$ & $(0.0148)$ \\
\hline 1 year prior & 0.0159 & -0.0190 \\
\hline & $(0.0558)$ & $(0.0171)$ \\
\hline Year of referendum & 0.0240 & -0.0299 \\
\hline & $(0.0562)$ & $(0.0150)^{* *}$ \\
\hline 1 year later & -0.0203 & -0.0253 \\
\hline & $(0.0633)$ & $(0.0226)$ \\
\hline 2 years later & 0.0227 & -0.0019 \\
\hline & $(0.0666)$ & $(0.0194)$ \\
\hline 3 years later & 0.0341 & -0.0189 \\
\hline & $(0.0608)$ & $(0.0244)$ \\
\hline 4 years later & 0.0440 & -0.0569 \\
\hline & $(0.0598)$ & $(0.0221)^{* *}$ \\
\hline 5 years later & -0.0087 & -0.0626 \\
\hline & $(0.0600)$ & $(0.0167)^{* * *}$ \\
\hline 6 years later & 0.0347 & -0.0297 \\
\hline & $(0.0661)$ & $(0.0165)^{*}$ \\
\hline 7 years later & 0.0082 & -0.0590 \\
\hline & $(0.0657)$ & $(0.0165) * * *$ \\
\hline 8 years later & 0.0595 & -0.0704 \\
\hline & $(0.0622)$ & $(0.0206)^{* * *}$ \\
\hline 9 years later & 0.0252 & -0.0512 \\
\hline & $(0.0614)$ & $(0.0139) * * *$ \\
\hline 10 years later & 0.0069 & -0.0005 \\
\hline & $(0.0773)$ & $(0.0132)$ \\
\hline
\end{tabular}

Notes: Results shown are from a single regression. The specification follows Equation (11) with the dependent variable being the $\log$ (construction permits+1), the key independent variables being referendum authorized spending per housing unit (split by funding for open space and funding for other purposes) interacted with three lead years, the year of the referendum, and 10 lag years. Controls include a third order polynomial in vote margin interacted with an indicator for passage and interacted with all lead and lag years, an indicator variable for the presence of a referendum interacted with all lead and lag years, proposed funding amounts interacted with all lead and lag years, year by census division fixed effects, a county level annual construction permit index, and municipality fixed effects. The number of municipality-year observations is 13,083 and the $R^{2}$ is 0.782 . Standard errors are shown in parentheses and are estimated using the Eicker-White formula to correct for heteroskedasticity and are clustered at the municipality level. *, **, and $* * *$ indicate significance at $10 \%, 5 \%$, and $1 \%$, respectively. 